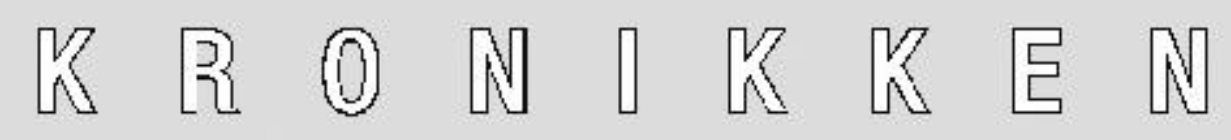

\title{
Velfærdssamfundet overladt til regnedrenge
}

af Peter Abrahamson og Rune Puggaard 
$\mathrm{H}$ vis velfærdskommissionen havde læst sine moderne sociologiske teorier, ville den vide, at dynamikker, der skaber såvel økonomisk effektivitet som social legitimitet, må understøttes. Imidlertid har velfærdskommissionen tabt den sociale legitimitet af sigte og satset ensidigt på økonomisk effektivitet.

\section{Kommisionen}

Regeringen ser socialpolitiske problemstillinger i lyset af økonomiske udfordringer, og store dele af kommissoriet omhandler den finansielle sikring af velfærdsstaten. Der er dog også nogle sociale parametre. På den ene side har kommissionen fået til opgave "at analysere den forventede udvikling i trækket på velfærdsydelser frem til $2020 \mathrm{og}$ mulighederne for at finansiere dette inden for rammerne af uændrede skatter". Det er kommissionens opgave at analysere forskellige muligheder for at finansiere velfærdsydelserne og at komme med konkrete forslag til reformer. Den anden side af kommissionens arbejde er at analysere den sociale balance i velfærdsydelserne og at sikre en socialt afbalanceret og målrettet indsats for at hjælpe de grupper, som har mest behov for hjælp.

Det kan derfor undre, at regeringen udelukkende satser på at finde løsningerne blandt økonomer, der er optaget af to forhold: Dels at øge incitamentet til at arbejde, og dels at der skal være en ligelig sammenhæng mellem betaling af skat og modtagelse af velfærdsydelser. Økonomernes dominans er navnlig besynderlig, når kommissionen beskrives som "en bredt sammensat, sagkyndig kommission om fremtidens velfærd. “ Kommissionen består af otte økonomer og en jurist og den bliver betjent af et øvrigt meget kvalificerede sekretariat, der desværre også er totalt domineret af økonomer. Det er derfor fristende at konkludere, at regeringen ikke har ønsket at nedsætte en velfærdskommission, men en velstandskommission, hvis fornemste opgave er at foreslå, hvordan man kan nedbringe de offentlige omkostninger til velfærden.

Formelt skal kommissionen foreslå reformer, der dels øger beskæftigelsesfrekvensen og dels sikrer, at fremtidens kloge og kreative hoveder bliver i Danmark, selvom det bliver lettere at flytte til andre lande, hvor skatten er mere gunstig. Kommissionen har indtil nu set på tre store udfordringer, hvilket fremgår af dens hidtidige rapporter: "Fremtidens velfærd og globaliseringen" (marts 2005), "Fremtidens velfærd - sådan gør andre lande" (marts 2005) og "Fremtidens velfærd kommer ikke af sig selv" med tre hovedkonklusioner (maj 2004):

-Globaliseringen stiller større krav til fleksibilitet og sætter skattesystemet under pres.

-En højere grad af aldring betyder, at der bliver færre i den erhvervsaktive alder.

- Øget individualisering kan medføre dalende ansvarlighed over for samfundet, samtidig med at borgerne i fremtiden ønsker bedre offentlig service. 


\section{Globalisering}

Globaliseringen kræver, ifølge velfærdskommissionen, at vi omlægger ydelser fra tunge indkomstoverførelser til investeringer i uddannelse, forskning og teknologi. Pensionsalderen betragtes som alt for lav, og man bør indføre delvis brugerbetaling på bl.a. videregående uddannelser, for at omlægningen kan lykkes. Endelig peger kommissionen på, at tendensen i andre lande er, at man lemper skatten på arbejdet $i$ både top og bund for dels at holde på den kvalificerede arbejdskraft og dels så det kan betale sig at arbejde. For det skal bedre kunne betale sig at arbejde, ellers risikerer Danmark, at den veluddannede del af befolkningen lægger deres skattekroner i udlandet. Dette fremgår af velfærdskommissionens to længe ventede rapporter fra 2005, der for alvor skulle sætte fokus på globaliseringens udfordringer for velfærdssamfundet.

Problemerne har længe været kendte inden for sociologisk og politologisk velfærdsforskning. I 2003 konkluderede forskeren Maurizio Ferrera, at den største risiko for destabilisering af velfærdssamfund findes inden for den skandinaviske model i en global kontekst, hvor arbejdskraftens ind- og udvandring stiger.

Problemet er, at det danske velfærdssamfund er baseret på en social kontrakt, hvor borgerne bliver født, vokser op og ikke mindst arbejder i Danmark hele deres liv. På denne måde skulle sammenhængen mellem de, der betaler skat, og de, der nyder sociale rettigheder, være sikret. Men kommissionen mener, at den danske model udfordres af globalisering og stigende vandring over landegrænser.

Årligt udvandrer ca. 15.000 danskere, og mange af disse er højtuddannede, men $3 / 4$ er vendt tilbage efter 6 år i udlandet. I 2002 var det kun $41,2 \%$ af de udvandrede danskere, der var i den erhvervsaktive alder. Kommissionen peger dog på, at det er kreative og kloge hoveder, der rejser ud, hvorimod indvandringen ikke modsvarer dette mønster. Indvandringen udgør nemlig en "underskudsforretning" for det offentlige. Dog medgiver den, at "problemet ikke er så stort endnu". Kommissionen hævder desuden, at mulighederne for at bruge traditionelle omfordelingsredskaber, som skatter, overførsler og høje mindstelønninger, begrænses af globaliseringen.

Konklusionen er altså, ifølge kommissionen, at det kræver reformer at fremtidssikre velfærdssamfundet, så offentlige ressourcer i højere grad bruges på opkvalificering end på overførselsindkomster.

Lad os være helt klare på dette punkt. Det er en politisk prioritering, at der er så få velkvalificerede indvandrere i Danmark. Det vil således også være muligt at ændre tiltagene for at øge den såkaldte "kvalificerede indvandring," hvis den politiske vilje var til stede. Åbningen for indvandring efter canadisk forbillede med green card-ordninger ville lette adgangen til Danmark betydeligt. Dette ville formentlig kunne tiltrække adskilligt flere højtuddannede, end der forlader Danmark om året.

Såfremt velfærdsydelserne ikke indkomstprøves, og brugerbetaling indfø- 
res på uddannelsessystemet, er Danmark yderst konkurrencedygtigt globalt set. For selvom det er muligt for den ene ægtefælle at tjene betydeligt mere i lande som Canada og USA pga. lavere skat og højere lønninger, så er omkostningerne til sundhed, uddannelse og pleje tilsvarende højere. For en børnefamilie er Danmark en attraktiv mulighed, der navnlig udgør et trygt alternativ til andre modeller. Det kunne selvfølgelig gøres endnu mere attraktivt at etablere sig i Danmark. Navnlig ved at lette adgangen til velfærdsydelser for den mobile arbejdskraft, der ikke nødvendigvis lever og bor i landet hele livet igennem.

Kommissionens konklusioner om globaliseringen overser på den måde to centrale politiske områder, nemlig indvandrerpolitikken og familiepolitikken. Begge udgør de andre skruer politikere kan dreje på.

\section{Aldring}

Aldringen i befolkningssammensætningen får kommissionen til at konkludere, at vi står over for en række smertefulde valg. Hvis velfærdssamfundet skal bevare samme niveau som i dag, skal bundskatten enten stige med $8,5 \%$, ellers skal det offentlige spare 3,5\% af BNP. Alternativt skal yderligere $274.000 \mathrm{i}$ arbejde. Kommissionen arbejder under den politiske forudsætning, der er fastsat af regeringen, at skattetrykket skal forblive uændret, og den anser det for urealistisk, at yderligere 274.000 marginaliserede skulle komme i arbejde. Derfor er offentlige besparelser og senere tilbagetrækningsalder de eneste politiske løsninger kommissionen arbejder frem i mod.

Men forudsætningerne er ikke kun politisk ensidige, de er også økonomisk ensidige. De er ovenud pessimistiske i forhold til både aldersbetingede udgifter og graden af offentligt finansierede pensioner. Som økonomiprofessor Jesper Jespersen skrev i Information 11/12 2004, valgte kommissionen at forlænge befolkningens levealder i forhold til den nuværende levetid med den konsekvens, at der blev mange flere dyre pensionister. Selv med denne ændring er der stadig et overskud på de offentlige finanser i 2021, problemerne opstår i først i 2041. Kommissionen forventer, at udgifterne til pleje for en 75-årig bliver de samme, uanset ændringerne i middellevetiden. Men hvorfor skulle vi ikke føje lige så meget liv til årene som år til livet, hvis middellevealderen stiger fra 79 til 85 år?

Sat på spidsen kan man tilmed sige, at hvis alderdommen kunne gøres mere aktiv med motion og sundere livsstil, så ville en stor del af udgifterne til ældrepleje og hospitaler kunne afværges. Populært sagt skal vi altså have langt flere af vores ældre medborgere ud at dyrke stavgang. Kommissionen har desuden pessimistiske forventninger til offentlige udgifter til pensioner. Den forventer, at pensionerne stiger med samme hastighed som lønudviklingen, men indtil nu har der været et efterslæb.

Det er uklart, hvorfor kommissionen maner en krisestemning op på baggrund af så usikre beregninger, hvis ikke det var fordi, den skulle skabe debat. Men selvom regeringen gerne vil legitimere velfærdsreformer, hvilket de fle- 
ste økonomer sådan set er enige om er nødvendige, så er Finansministeriets egne fremskrivninger under halvt så pessimistiske som kommissionens. Velfærdskommissionen peger på, at vi kommer til at mangle 68 mia. kr. i år 2040, hvorimod Finansministeriets beregninger viser, at manglen er på blot $27 \mathrm{mia}$. $\mathrm{kr}$.

\section{Individualisering}

Kommissionen ser stigende individualisering, der også afsætter sig i krav om bedre og dyrere offentlig service og ydelser, som tredje og fjerde udfordring til velfærdssamfundet. Hvis disse krav skal honoreres, kræver det, ifølge kommissionen, yderligere reformer.

Individualiseringen truer modellens sammenhængskraft af to grunde: 1. Dels fordi vi får for gode muligheder for at trække os tilbage fra arbejdsmarkedet. 2. Dels fordi vi tilskyndes til at sikre os størst muligt personlig adgang til velfærdsrettigheder. Ingen af delene påvirker nemlig vores skattebetaling. Konklusionen er velkendt, og den peger entydigt i retning af det, der hele tiden har været kommissionens præmis: "Det skal kunne betale sig at arbejde" og rettigheder og pligter skal justeres efter princippet "noget for noget".

Det skal kunne betale sig at arbejde

Kommissionens model er baseret på, at lønmodtagerne antages at have et suverænt valg mellem arbejde og fritid, og at dette valg er bestemt af forskellen mellem éns løn efter skat og offentlige indkomstydelser, såsom kontanthjælp og efterløn. Det er lønmodtagernes incitament til at arbejde, der afvejes over for nettoindkomsten ved ikke at arbejde. Skal beskæftigelsen øges, kan det kun ske ved, at velfærdsydelserne reduceres. Derfor er det måske ikke så underligt, at kommissionen til stadighed foreslår både strategiske skattelettelser og nedskæringer i ydelser, der hæmmer lysten til at arbejde.

Hvis vi kigger på den gruppe af offentligt forsørgede, som denne politik er rettet imod, så er det tydeligt, at den samlede gruppe er på ca. 900.000. Heraf er nogle legitimt på overførelsesindkomst, så som forældre på barsel og efterlønnere, og andre 250.000 er på førtidspension. De står ikke til rådighed for arbejdsmarkedet. Den gruppe, der formelt står til rådighed for arbejdsmarkedet, er på ca. 250.000 , hvoraf godt og vel $1 / 4$ er på kontanthjælp. Denne gruppe skæres over én kam og mødes med budskabet om, at det skal kunne betale sig at arbejde. I praksis betyder det, at gruppen skal have mindre til rådighed. Tilgangen viser sig at være effektiv over for nogle grupper, såsom studerende. Men for den store gruppe af kontanthjælpsmodtagere har SFI for nyligt påvist, at øgede incitamenter ikke bringer flere i arbejde. Det nedsætter imidlertid rådighedsbeløbet og skaber således fattigdommen.

Dette eksempel er illustrativt for de problemer, som velfærdskommissionen løber ind i, når den grundlæggende og noget unuancerede præmis er: Det skal bedre kunne betale sig at arbejde, og så skal arbejdet nok opstå. Dertil kom- 
mer, at den økonomiske analyse af individualiseringens konsekvenser er unuanceret, idet den ser bort fra individualiseringens skyggesider. Det er nemlig sikkert, at individualiseringen skaber (refleksiv) sårbarhed blandt persongrupper, der ikke kan overskue kravene om uddannelse, arbejdsmarkedsparathed og konstant udvikling. Denne problematik burde være central for en velfærdskommission, men den forvandles til et spørgsmål om økonomiske incitamenter.

Efterlønnen er tillige for skud, idet kommissionen sætter ordningen lig med at nedsætte den generelle pensionsalder. P.t. er der nemlig ikke incitament til at fortsætte på arbejdsmarkedet for lavtlønnede. Men kommissionen tager ikke højde for, at der i fremtiden vil være mange veluddannede lønmodtagere, der statistisk set trækker sig tilbage senere. Derudover kræver efterlønsreformen, at man skal betale og være tilmeldt efterlønsordningen 25 år for at være berettiget til den. Hvad værre er, er at enhver finanspolitisk sammenhæng mellem beskæftigelse og offentlig efterspørgsel synes at være tilsidesat til fordel incitamenttankegangen.

\section{Noget for noget}

Kommissionens "noget for noget" tankegang, der taler for, at det skal kunne betale sig at deltage i velfærdens forsikringsordninger, er en anden grundpille i kommissionens arbejde. Ifølge kommissionen er problemet, at velfærdsstaten tilskynder borgerne til at tilrane sig ydelser, fordi skatten ikke påvirkes heraf.

Følger man denne tankegang bliver det afgørende spørgsmål, hvorfor den brede middelklasse skulle fortsætte med at bakke op om velfærdssamfundet. De er nemlig for store deles vedkommende netto-bidragydere til et system, der giver fribilletter til velfærdsydelserne. Kommissionen peger da også på, at denne ubalance er uholdbar.

Derfor fremstår det som en gåde for kommissionen, hvorfor velfærdssamfundet stadig har opbakning bag sig. På trods af dilemmaet viser danske vælgerundersøgelser bred opbakning til velfærdsamfundets kerneydelser. Det har blandt andre Jørgen Goul Andersen gjort opmærksom på ved flere lejligheder. Goul Andersen peger på, at grunden til opbakningen er, at netto-bidragyderne også oplever, at deres velfærdsbehov er dækket. Opbakningen er således betinget af velfærdsordningernes bredde. Hertil kommer i øvrigt, at opbakningen er betinget af, at velfærdssystemet $i$ øvrigt opleves som retfærdigt og gennemskueligt. På den måde bliver det danske velfærdssamfund til et fælles politisk projekt, som vi alle solidariserer os med.

Alt i alt er det således, at hensynet til økonomisk effektivitet bør sammentænkes med hensynet til social legitimitet. Middelklassens opbakning til den universelle velfærdsstat baserer sig ikke på "krone for krone" beregninger. Den ensidige cost-benefit tankegang, som kommissionen lægger op til med dens individualiseringstese, forklarer dårligt velfærdstatens enestående evne til at producere opbakning til kerneydelser. På foranledning af regeringen har kommissio- 
nen fasttømret en ny dagsorden for velfærdssamfundet, der i mindre grad baserer sig på sociale dynamikker og i højere grad på kommissionens økonomiske kalkuler.

\section{Legitimitet}

Det kunne have været oplysende for kommissionen at se velfærdsdiskussionen ud fra velfærdsteoretikere som Claus Offe og Jürgen Habermas. De anskuer velfærdsstaten som et tovtrækkeri imellem økonomisk effektivitet og social legitimitet. Kort fortalt giver velfærdsstaten økonomisk effektivitet til markedet $i$ form af bl.a. et fleksibelt arbejdsmarked, en uddannet arbejdskraft og en skattestrukturer, der skaber incitamenter til at indgå på arbejdsmarkedet. Omvendt skaber velfærdsstaten social legitimitet, når den kan bibringe borgerne social tryghed, sikre tilliden til at velfærdsydelserne er gennemskuelige og retfærdige og skabe villighed til at betale skatter.

Anskuer vi kommissionen ud fra dette tovtrækkeri mellem økonomisk effektivitet og social legitimitet, så er det tydeligt, at regeringen har givet økonomisk effektivitet forrang. Velfærdskommissionen har bidraget til at identificere udfordringerne i fremtidens Danmark, men den tilsidesætter fuldstændig hensynet til de dynamikker, der skaber bred opbakning til velfærdssamfundet, når den anbefaler flere private forsikringer, øget brugerbetaling og indkomstprøvning af offentlige ydelser. Økonomiske reformer, incitamenttankegangen og individualisering synes $i$ al for høj grad at gennemsyre kommissionens velfærdsdebat.

At folk lever længere og er mere mobile, stiller velfærdssamfundet over for økonomiske udfordringer, men reformerne må tage højde for, at middelklassen stadig skal opleve, at den bliver tilgodeset igennem almene velfærdsordninger. Ønsker vi at bevare velfærdssamfundets sociale legitimitet, skal vi undgå, at normen bliver indkomstprøvning af uddannelse, børnecheck, folkepensionen og sygesikringen. I en sådan ordning er det tvivlsomt om middelklassen vil betale til velfærdssamfundet uden selv at være en del af det. Det har som konsekvens, at middelklassens solidaritet eroderer, og med i faldet tager den hele velfærdssystemet.

Reformer er et væsentligt element $i$ at fremtidssikre velfærdssamfundet. Men det er ikke lige meget, hvordan fremtidssikringen sker, hvis vi også ønsker, at morgendagens samfund skal være et velfærdssamfund, der baserer sig på en bred solidaritet blandt hele befolkningen.

Peter Abrahamson

E-mail: Peter Abrahamson@sociology.ku.dk

Rune Puggaard

E-mail: Rune.Puggaard@ft.dk 